\title{
San Petersburgo: la ciudad de los muertos vivientes en la literatura y las creencias populares rusas
}

\author{
Elena Mironesko Bielova \\ Universidad de Granada (España) \\ elenamb@ugr.es
}

Recibido: Octubre de 2011

Aceptado: Febrero de 2012

\begin{abstract}
Resumen
El presente estudio tiene por objetivo analizar la percepción de San Petersburgo en la mentalidad rusa y en la creación literaria, donde se refleja la visión de la capital imperial como ciudad apocalíptica poblada por dobles, fantasmas y muertos vivientes. Esto se explica ante todo por la propia historia de la metrópoli, fundada por el Zar Pedro I, considerado a su vez por muchos de sus coetáneos como la encarnación de las fuerzas del Mal.
\end{abstract}

Palabras clave: folclore urbano, literatura rusa, San Petersburgo.

\section{St. Petersburg: the City of the Living Dead in Russian Literature and Folk Beliefs}

\begin{abstract}
The aim of the present study is to analyse the perception of St Petersburg from the Russian frame of mind. It also examines the literary activity which reflects an overview of the imperial capital seen as the apocalyptic city inhabited by lookalikes, ghosts and zombies. The aforementioned can be explained by the very history of the metropolis, founded by Czar Peter I who was considered the personification of Evil by most of his peers.
\end{abstract}

Key words: Russian culture, literature, Saint Petersburg.

A lo largo de toda su existencia el ser humano ha estado ansioso por descubrir lo que está más allá de la muerte, lo que le espera al cruzar el umbral entre la vida y el inevitable final de su camino. La inquieta mente popular buscaba y encontraba en lo más cercano y cotidiano las "claras" huellas e "indiscutibles muestras" de presencia de las criaturas que venían desde el otro lado de la cortina que separa ambos mundos. Esta inagotable curiosidad, combinada a la vez bien con auténtico y sincero miedo, bien con morboso y macabro encantamiento, sigue vigente incluso en nuestros tiempos de logros científicos y tecnológicos. Los seres de ultratumba atrapan la atención, "embrujan" a los hombres y mujeres del siglo XXI, lo que se refleja en gran cantidad de obras literarias y cinematográficas de indiscutible éxito comercial. 
Al mismo tiempo, el tema se convierte en el eje principal de estudios antropológicos, folclorísticos, literarios, teológicos, etc., y reúne a filólogos, filósofos, especialistas en historia del arte, médicos, para tratar desde distintos puntos de vista las perennes creencias populares en los vampiros, zombis, y fantasmas ${ }^{1}$.

Analizando la presencia de las más variopintas criaturas del más allá en las creencias de los eslavos orientales, en sus mitos, leyendas y distintas muestras de cultura popular, así como el inevitable reflejo de su existencia en las creaciones literarias, un atento estudioso o un apasionado lector forzosamente se encuentra con la impactante figura de un repugnante ser de ultratumba. El maligno personaje se llamaba yпырь (upyr) y era un muerto muy vivo. A veces los upiros en el folclore eslavo se asemejan mucho a los clásicos vampiros chupasangre, en otras ocasiones son más parecidos a zombis, unos walking dead. En numerosas obras literarias leemos sobre los upiros, que salían de sus tumbas para beber sangre o comer carne humana ${ }^{2}$.

Reflexionando sobre tan ambigua y tan diferente figura en las distintas zonas eslavas orientales, incluso dentro de las creencias del mismo pueblo ruso, nos hallamos en un ambiente donde, al parecer, los muertos vivos se encontraban especialmente a gusto y en grandes cantidades. Seguramente a la memoria de muchos vendrían las imágenes de espesos bosques siberianos, profundos lagos y pantanos, donde suelen habitar seres poderosos y peligrosos. Y, por supuesto, no faltan por allí las brujas, los más variopintos demonios y duendes, las sirenas y otras criaturas fantásticas del folclore eslavo.

Desde luego, los que han pasado por la ciudad de San Petersburgo, la antigua capital del Imperio Ruso, una de las ciudades más bellas y elegantes del mundo, se asombrarían al saber que justamente esta ciudad gozó durante toda su historia de la dudosa fama de ser la ciudad del Anticristo, donde habitan seres demoniacos, donde cada rincón esconde un peligro de caer en las garras de los siervos de Diablo, detrás de cada sombra se percibe el rostro del Príncipe de las Tinieblas. Aquí, en la ventisca invernal o en las misteriosas noches blancas, los miles de espejos de majestuosos palacios, las oscuras ventanas de humildes moradas y la superficie lisa y brillante de los canales y ríos no devuelven el reflejo a muchos de los pobladores de la ciudad, quienes sólo aparentemente son totalmente normales, con sus ordinarias obligaciones laborales y familiares, y quienes son en realidad representantes de las fuerzas del más allá.

Sin embargo, tan chocante -a primera vista- visión está muy arraigada en la memoria colectiva de esta ciudad europea y en la mentalidad popular rusa en general, encontrando su explicación en la propia Historia rusa debido -sobre todo- a la figura de su fundador: el zar Pedro I El Grande 3 .

\footnotetext{
1 Por ejemplo, en la Universidad de Granada se organizaron y realizaron con gran éxito dos cursos multidisciplinares: “Cuándo se le rompió el espejo al Vampiro? El Mito del Vampiro a través del arte, la ciencia y la cultura” (2010) y "Vampiros a Contraluz. Constantes y Modalizaciones del Vampiro en el Arte, la Ciencia y la Cultura" (2011).

2 Tratamos el tema en la conferencia "El Vampiro en los pueblos eslavos orientales: historias para no dormir", impartida en el curso “¿Cuándo se le rompió el espejo al Vampiro? El Mito del Vampiro a través del arte, la ciencia y la cultura" (6 de abril-13 de abril de 2010).

${ }^{3}$ La majestuosa y al mismo tiempo contradictoria personalidad del gran regidor ruso ha sido a lo largo de siglos objeto de numerosos estudios, tanto elogiosos como críticos; véase, por ejemplo, HUGHES (1998), HUGHES (2002), MASSIЕ (1987), АНИСИМОВ (1989), БУГАНОВ (1989), ВАЛИШЕВСКИЙ (2003), КЛЮЧЕВСКИЙ (2002), ЧИСТЯКОВ (1992) у muchos otros, incluyendo nuevas y polémicas publicaciones: БУРОВСКИЙ (2008), ЩЕГЛОВ (2010).
} 
Es imposible abarcar, aunque en términos generales, todo cuanto hizo el Zar Reformador para convertir una Rusia atrasada, conservadora y retrógrada en un estado moderno, próspero y a la altura de los más poderosos y modernos países europeos. Las reformas del emperador afectaron todos los estratos y aspectos de la vida económica, administrativa, política, etc.

Aquellos cambios y transformaciones afectaron muy de cerca la vida cotidiana. Muchos de ellos al principio pudieran parecer una simple anécdota, como por ejemplo, la prohibición a los hombres rusos de llevar barba y la obligación de afeitarse diariamente, así como vestirse a la occidental (la ropa tradicional, con largos faldones, se permitía solamente a los campesinos y al clero), etc. Pero si tenemos en cuenta que la barba para un hombre ruso era todo un símbolo de sabiduría, seriedad, responsabilidad y lealtad a los principios religiosos, comprendemos el impacto que tuvo esta normativa para la mentalidad colectiva: fue considerada un fuerte golpe a los principios tradicionales rusos. Afeitarse la barba fue, para los nobles rusos, equivalente a salir desnudos a la calle, como perder su dignidad, y fue ciertamente muy traumático. Así pues, el propio zar se divertía cortando personalmente las barbas a sus súbditos y cortesanos. Los que se empeñaban en lucir la barba tenían que pagar un impuesto especial y exhibir una medalla que confirmaba este pago.

Las tímidas jovencitas de las familias ricas tenían que salir de sus casas, donde estaban acostumbradas a rezar y a esperar a sus futuros maridos en obediencia y modestia, a participar en las fiestas multitudinarias llamadas ассамблеи -asambleas- $y$ que, a menudo, conociendo el fuerte carácter del emperador, tomaban un cariz auténticamente salvaje.

A los mozos nobles, el zar reformador los sacó de una vida perezosa y hedonista, obligándoles a viajar por Inglaterra, Alemania, Holanda y otros países europeos para aprender ciencias y oficios, convertirse en ingenieros, oficiales de marina, militares cualificados, científicos y arquitectos, que tanto necesitaba el renovado país. El propio zar, que - de incógnito, eso sí- estuvo mucho tiempo por esos países aprendiendo diversos oficios - entre ellos el de carpintero de ribera-, fue bien conocido en Inglaterra, donde al parecer dejó unos muy lamentables recuerdos entre los refinados nobles ingleses, como resultado de su rudo y tosco comportamiento en ruidosas francachelas e increíbles fiestas, o de destrozar la noble casona o palacete donde se había alojado (COWLES 1975: 40).

Por otro lado fueron invitados a Rusia muchos extranjeros cualificados, quienes formaban auténticas zonas residenciales en las grandes ciudades y traían consigo sus fiestas y costumbres, las cuales no comprendían los rusos. Las simpatías del zar hacia los extranjeros dieron pie a numerosos rumores y leyendas. Así, decían que su madre, la zarina Natalia Kiríllovna, había dado a luz a una niña y que, para complacer al padre, el zar Alekséi Mijáilovich, garantizándole un heredero, encontraron en el barrio alemán a un bebé e hicieron creer al zar que habían nacido gemelos -una niña y un niño-, pero que, en realidad, el niño era alemán. Por esa razón al zar le gustaban más los foráneos y otorgaba favores y privilegios a los extranjeros (СИНДАЛОВСКИЙ 1994: 7).

Todas las reformas -tanto las más grandes e importantes que afectaban el funcionamiento de todo el estado ruso, como las aparentemente más insignificantes, que 
se introducían en la vida privada de los ciudadanos, pero justamente por eso les tocaban de manera directa- no podían sino causar una reacción de enérgico rechazo por parte de los estratos sociales opuestos a estos cambios. Recordaremos que la propia hermana del zar, la princesa Sofía, encabezó estos movimientos (1657-1704).

Obviamente, las rebeliones contra las reformas y la política del zar fueron cruelmente sofocadas. Así, la sublevación de los mosqueteros llamados стрельиьь (1698) fue aniquilada con increíble crueldad. El zar modernizador no anduvo a la zaga del sangriento Iván el Terrible:

Después de la tortura llegaron las ejecuciones. Pareciéndole que los capataces eran demasiado lentos en su tarea, Pedro cogió él mismo el hacha y con ella hizo rodar por tierra las cabezas de sus súbditos, a guisa de gigante regio, de facciones deformadas, con los labios llenos de espuma y las ropas manchadas con la sangre de sus víctimas. Pedro invitó a los extranjeros que se hallaban a su servicio a que le ayudasen en el castigo, pero Lefort y Von Blomberg declinaron este peregrino honor alegando que ello sería incompatible con sus códigos nacionales de comportamiento (SCHAKOVSKOY 1964: 300).

Las luchas entre Pedro I y sus seguidores contra los enemigos internos no sabían de parentescos. Igual actuó contra su hermana, o contra su esposa, a la que obligó a tomar los hábitos y la recluyó en un alejado monasterio, si bien ella no había dado motivo alguno para merecer tal castigo (normalmente se acusaba a esposa de infidelidad); tampoco tuvo piedad con su propio hijo Alekséi: al tener constancia de que Alekséi había participado en un complot contra su padre, éste lo interrogó personalmente aplicándole horribles torturas y posteriormente el zarévich y otros rebeldes fueron ejecutados (1718).

Una de las más importantes causas de estas numerosas protestas y rebeliones fue, sin duda alguna, el fuerte cambio en las relaciones con la iglesia ortodoxa. Muy profunda fue la reforma eclesiástica: fue abolido el concepto de Patriarcado y se creó un nuevo órgano que administraba los asuntos de la iglesia: el Sínodo. Lo que obviamente no gustó a las autoridades de la iglesia ortodoxa, que veían cómo de un plumazo perdían todo el inmenso poder que habían detentado a lo largo de varios siglos. Recordaremos que justamente Pedro I adoptó el calendario gregoriano, en vigor en todos los países europeos desde el año 1582. Sin embargo, la iglesia ortodoxa no aprobó este cambio y, hasta hoy, toda la liturgia, las fiestas y las fechas del calendario ortodoxo se rigen por el calendario juliano. Tampoco agradó a la población rusa la orden, emitida durante la guerra con Suecia, de retirar las campanas de los campanarios de las iglesias para fundirlas y convertirlas en cañones.

En todos los aspectos de su vida el zar demostró su desprecio por los fundamentos e instituciones de la iglesia ortodoxa rusa. Eran bien conocidas sus burlas, como, por ejemplo, un grotesco rito durante el cual Pedro y sus amigos se disfrazaban de patriarcas y obispos y recorrían las calles seguidos por el así llamado Пьяный Синод ("Sínodo Borracho"), formado por los hombres más disolutos. A su vez, las propias reuniones de este rocambolesco y libertino grupo representaban unas auténticas orgías empapadas de espíritu anticlerical ${ }^{4}$.

\footnotetext{
${ }^{4}$ Sobre el carácter lascivo y blasfemo del “Сумасброднейший, всешутейший и всепьянейший собор”, véase con más detalle en ТРАХТЕНБЕРГ (2005: 89-118) у ЩЕГЛОВ (2010).
} 
Se mofaba de la gente y se divertía humillando a los más respetables. Así, cuando el anciano Mateo Golovín, miembro de una de las más nobles familias de Rusia no quiso tomar parte en estas fantasmagóricas cabalgatas disfrazado de diablo, lo desnudaron, le pusieron en la cabeza un casquete con cuernos y lo obligaron a sentarse durante una hora sobre el helado río Nevá, suplicio que días después causó el fallecimiento del octogenario noble.

Los bien conocidos juegos y burlas, la ajetreada vida privada -tras recluir a su primera esposa en un apartado monasterio se casó con Marta Skavronska, una sirvienta de origen lituano traída a Rusia como botín de guerra, y que posteriormente se convirtió en la emperatriz Catalina I-, confirmaba la percepción de Pedro I como símbolo del pecado y del vicio ${ }^{5}$. Según los defensores y guardianes de las viejas tradiciones, los rusos empezaron a ser tenidos por latinos infieles, y las reformas relacionadas con la iglesia fueron las más dolorosas para aquéllos. El cambio del calendario, la prohibición de las procesiones religiosas, las burlas de las reuniones tradicionales de las autoridades eclesiásticas, la eliminación del Patriarcado, etc., crearon entre la población la percepción de que en Rusia gobernaba el Anticristo. Al zar lo llamaban "maldito, bestia, orgulloso príncipe del mundo terrenal". Decían "Pedro es el Mal del mundo, predador y bandido de la Iglesia, orgulloso y cruel cazador". Asimismo lo denominaban bestia bicéfala, puesto que se autonombró la cabeza del poder eclesiástico y del poder secular y se le atribuían repugnantes milagros. Encontraron haciendo cábalas el número diabólico 666 en su reinado. Incluso el nacimiento de Pedro de la unión del zar Alekséi y su segunda mujer se consideraba pecaminoso.

De este modo, percibiendo a Pedro I como el Anticristo, su época se veía como apocalíptica. De aquí no es de extrañar que cuando el zar tomó la decisión de fundar una ciudad nueva, moderna y europea a orillas del río Nevá, fortaleciendo de esta manera la presencia de Rusia en el Báltico, la propia ciudad, que fue nombrada San Petersburgo, en seguida obtuvo la dudosa fama de ser la cuidad del Anticristo, donde se rompen todos los fundamentos de la auténtica fe, se eliminan los cimientos de la cultura y la tradición rusas, gobiernan los latinos infieles y reina el pecado.

Para la construcción de la nueva capital se necesitaban muchos materiales de construcción, de aquí que Pedro I obligase a todos los que venían a la ciudad a traer piedras para poder edificar sobre el terreno pantanoso. Pero además fueron paradas todas las obras en iglesias y monasterios en todo el país, un hecho que fue comprendido como un ataque más contra la Iglesia y la religión cristiana en general. De este modo, con cada normativa y cada orden relacionadas con San Petersburgo, la urbe ganaba numerosos enemigos. Sobre la nueva capital -erigida y construida sobre tierras pantanosas y de manera casi milagrosa- comenzaron a circular y a propalarse inquietantes y oscuros rumores.

Tampoco podemos olvidar los antecedentes históricos, ya que aquellas tierras pertenecieron antaño a los pueblos fineses y en aquella época gozaban de muy mala

\footnotetext{
5 Este matrimonio entre Pedro y Catalina, según el punto de vista dogmático de la iglesia ortodoxa, resultaba imposible y sacrílego ya que, al ser bautizada Catalina por el rito ortodoxo, el zarévich Alekséi actuó de padrino y ella se convirtió automáticamente en nieta (внучатая крестнииа) del zar (ДОМ РОМАНОВЫХ 1992: 35).
} 
fama entre los nuevos pobladores eslavos. En el folclore finés se guardan numerosas referencias y leyendas sobre esta parte del Mar Báltico, cuya idea principal es que el territorio estaba maldito por Dios y era mortífero para los hombres. Así, solamente quien tuviese poderes en el mundo del más allá sería capaz de fundar aquí una ciudad.

Después de la muerte de Pedro I, la nueva capital del Imperio causaba pánico y angustia entre sus habitantes, buscando ellos cualquier oportunidad y pretexto para huir de la maldita urbe. Por lo tanto, las autoridades tomaron drásticas e inhumanas medidas:

Такое запустение города вызвало со стороны правительства принудительные меры, и вскоре явился указ (15 июля 1729 г.), по которому заселение Петербурга опять сделалось налогом: велено было немедленно выслать на бессрочное житьё в Петербург всех выбывших из него купцов, ремесленников и ямщиков с их семействами, а за неисполнение или медленность повелено было отбирать все имение и ссылать вечно на каторгу. Эти строгие меры не привели ни к чему, народ тяготился житьём в Петербурге, ... (ПЫЛЯЕВ 1990: 89-90).

"Петербургу быть пусту" - "San Petersburgo estará vacía". Se cumplía la maldición o profecía pronunciada por Eudoxia Lopujiná, la primera esposa del zar, quien, como se apuntó anteriormente, fue recluida por su marido y terminó su vida en la oscuridad de una celda monacal. Posteriormente esta frase fue repetida por todos los adversarios de las reformas del emperador y fue reflejada en abundante documentación de archivos relacionados con los complots contra el gobierno. Prediciendo la muerte, la despoblación y todo tipo de desgracias que tenían que caer sobre la apocalíptica ciudad y sobre los siervos pecaminosos del Anticristo, avisaban del castigo divino en forma de desastres naturales, ante todo de horribles inundaciones. Situada la ciudad sobre tierras pantanosas, a orillas del río Nevá y cercana al Mar Báltico, ya al tercer mes de su existencia los pobladores de San Petersburgo se enfrentaron a una inundación que se cobraba miles de vidas. En la noche del 19 al 20 de agosto el agua subió más de dos metros, y si tenemos en cuenta que con escasos 40 centímetros se inundaba completamente, podemos imaginar que los rumores sobre el carácter diabólico de la nueva urbe y el castigo divino encontraban tierra abonada.

En total, durante el reinado de Pedro I, entre los años 1703-1725, hubo once inundaciones, contando en este caso solamente las más importantes y devastadoras, con muchas víctimas mortales, que superaban los $150 \mathrm{~cm}$. de subida del agua. Se sabe que en 1777, cuando el nivel del agua subió hasta $310 \mathrm{~cm}$., fallecieron miles de ciudadanos. En 1824, con una subida de $410 \mathrm{~cm}$., la inundación destruyó 462 edificios y causó graves desperfectos a otros 3681. En 1924 (con $369 \mathrm{~cm}$. de subida) se anegó la mitad de la urbe, se destruyeron 19 puentes y resultaron gravemente afectados más de 5000 edificios. Y aunque la ciudad conoció después otras inundaciones mucho más fuertes, sin duda alguna, la más impactante y con consecuencias políticas significantes fue la primera. El castigo de Dios caía sobre la ciudad de los infieles, de los pecadores y de los traidores de la fe cristiana y confirmaba las leyen- 
das sobre su origen diabólico y su terrible destino.

Los antiguos creyentes, que se oponían a las reformas del Patriarca Nikon (16661667), menos aún estaban por aceptar las reformas de Pedro El Grande. Muchas leyendas y creencias sobre la ciudad de Anticristo salieron de las comunidades de los antiguos creyentes, ferozmente perseguidos por el poder. Así, les permitieron abrir su propio lugar de rezos solamente en el año 1905, pero aun así, existe entre los seguidores de este movimiento religioso la firme tradición de no vivir dentro de los límites de San Petersburgo, ni en sus alrededores. Cuentan que durante la inundación del año 1924, una de las más fuertes en la historia de la ciudad, algunas familias se reunieron en las fosas comunes del Campo de Marte, y estando con el agua hasta la cintura, rezaban en voz alta, sin disimular su alegría, porque "ya ha llegado la hora para cumplir la predicción sobre el final de la ciudad, construida por el Anticristo en las profundidades pantanosas".

Durante el reinado de Catalina II (1762-1796), con el claro propósito de demostrar que la zarina era la sucesora directa de la política de Pedro I, se erigió un magnífico monumento, que con el paso de tiempo se convirtió en símbolo de la ciudad: Медный Всадник ("Jinete de cobre", conocido en Occidente como "Caballero de Bronce"). Esculpido por el francés Étienne Falconet entre los años 1768-1770 impresionó de tal modo a los ciudadanos que al mismo tiempo dio origen a numerosas leyendas:

... Это был не просто всадник («Медный Всадник»), это был символ, в иных случаях просто Медный Всадник, но чаще он варьировался, видоизменялся: он был и всадником, и видением одновременно. Произошла любопытная метаморфоза: тот, стоящий на скале, приобрёл апокалипсические черты, а другой, сошедший со страниц Апокалипсиса, стал походить на фальконетовское изображение (СИНДАЛОВСКИЙ 1994: 26).

El jinete que está sobre un caballo enfurecido mirando hacia un abismo es el jinete del Apocalipsis, el caballo pálido, que apareció después de quitar el cuarto sello, el jinete cuyo nombre es La Muerte, y el infierno le sigue, y tiene poder sobre la cuarta parte de la tierra, mortificada con la espada, el hambre y las bestias terrenales. Todo coincidía con la profecía, incluso la mención de la cuarta parte de la tierra. Por tanto no es de extrañar que en esta ciudad, creada por el mismo Anticristo, encontraran cobijo numerosos brujos, magos y demás personas que habían pactado con el Diablo. Así, corrían inquietantes rumores sobre el brujo y alquimista Brius. Más tarde, en esta fría y bella ciudad el poeta Aleksandr Pushkin situó la historia de "Пиковая дама" ("La Dama de Picas", 1834) con una repugnante bruja y la muerte que acecha a sus personajes; aquí se guardaba testimonio de numerosos fantasmas que habitaban tanto en los palacios y mansiones de ricos y nobles como en las casas de pobres y de estrato social humilde.

La aparición de espectros en el folclore petropolitano es una muestra inequívoca de que se trataba de una ciudad europea, heredera de las tradiciones de la cultura occidental. Comparados con los de las leyendas de fantasmas en otras culturas de Europa occidental, los de San Petersburgo casi siempre están personificados, son 
personajes de la historia y, si no es así, fácilmente reconocibles por sus apodos -El Constructor, El Monje, El Arquitecto, etc.-. No tan frecuentes son los fantasmas anónimos.

Desde sus primeros días como capital imperial, circularon entre sus pobladores historias sobre las criaturas del más allá. La existencia de numerosos seres fantásticos se interpretaba como mal augurio para la ciudad y la difusión de estos rumores se castigaba por las autoridades sin piedad. Se ha conservado abundante documentación en los Archivos de la Cancillería Secreta, con textos de interrogatorios correspondientes a los casos de difusión de historias y rumores que predecían el cercano final de la diabólica ciudad.

Las primeras leyendas versaban sobre criaturas bien conocidas por la tradición folclórica rusa, pero ya pronto surge la propia mitología de San Petersburgo. De hecho, los especialistas hablan no solamente de la mitología de esta ciudad, sino también de la existencia de un espacio mitopoético especial, llamado el texto petersburgués 6 .

Los primeros fantasmas, muertos no-muertos, eran los trabajadores que morían en la construcción de la nueva capital. Pero justo después de su muerte, el fantasma más activo y propiamente petersburgués fue el propio fundador de la ciudad. Las leyendas, rumores y cuentos que narraban y pasaban de boca a boca acompañaban al zar desde su nacimiento. Numerosas son las leyendas que cuentan las predicciones de sabios y astrólogos sobre el nacimiento del futuro regidor. También circulan otras leyendas que ponen en duda el origen ruso de Pedro. En algunas historias, su padre es Lefort, en otras, procede de una aldea finesa. Asimismo circulaban rumores en el sentido de que el joven Pedro, estando en Suecia, fue capturado y en su lugar enviaron a Rusia a un impostor. Eso explica por qué el zar, al regresar de su viaje por tierras extranjeras, no fue a rendir honores a los santos rusos, que era la costumbre, ni fue a visitar las tumbas de sus padres, sino que se dirigió directamente al barrio alemán para montar allí una fiesta con sus amigos, lo que se podía explicar solamente por su origen no-ruso.

Pero incluso cuando el zar intentaba reconciliarse con la religión ortodoxa, el mundo cristiano no lo aceptaba. Existen varias leyendas sobre un acontecimiento histórico que sucedió en 1724. En aquellas fechas, Pedro I decidió traer a San Petersburgo los restos mortales del santo Aleksandr Nevski. Entre los numerosos rumores que dudaban de la autenticidad y presencia de los restos en el relicario de la catedral, y que acusaban al zar de fraudulento, circulaba uno muy peculiar: Pedro habría traído dos veces los restos del santo a la ciudad y las dos veces, los restos no quisieron permanecer en la ciudad del Diablo, regresando misteriosamente al lugar donde se custodiaban anteriormente. A la tercera -cuenta la historia- Pedro decidió cerrar el ataúd con llave y la arrojó al río Nevá. En ese momento, cerrando Pedro la tumba, se oyó una débil voz: -"¿Para qué todo eso? Sólo para trescientos años”. Al girarse, el emperador vio una figura vestida de negro que se alejaba. Así, según tal leyenda, la ciudad tendría que desaparecer en 1924.

\footnotetext{
${ }^{6}$ Véase una interesante monografía de ТОПОРОВ (2003).
} 
Al morir Pedro I, cuanto estaba relacionado con él adquirió un matiz místico y macabro. Muchos cuentos de terror están relacionados con la figura de cera de Pedro, realizada aún en vida del emperador. Vestida con su propia ropa, con el cabello natural del zar y con una máscara moldeada del rostro del propio Pedro I, daba miedo a todos los que la veían y consideraban que tomaba vida.

Los testimonios de ver al fantasma de Pedro I son numerosos y forman una importante parte de la mitología urbana. Así, cuentan que al joven Pablo -el futuro Pablo I-, cuando paseaba por la ciudad con un amigo y varios sirvientes, se le acercó un desconocido, diciendo -"Pablo, pobre Pablo, Pobre príncipe. Yo soy aquel que se preocupa por ti". Y después, entrando en la Plaza del Senado, le predijo "Adiós, Pablo, me verás de nuevo aquí". El joven zarévich reconoció en el hombre a Pedro I, relató lo sucedido a su madre, la emperatriz Catalina II, la cual interpretó el episodio como una señal indicativa de dónde había que erigir el monumento a Pedro -el ya mencionado Caballero de Bronce--. Lo curioso de esta leyenda es que fue casi oficial y totalmente aceptada como una historia verídica. Parece que a partir de aquel encuentro Pablo veía a menudo al fantasma de su bisabuelo, y desde la construcción del castillo Mijáilovski, donde Pablo fijó su residencia, allí, por los pasillos de este inquietante palacio se oían los pasos del fundador de la ciudad. En sus apariciones, el espectro avisaba a su bisnieto de su muerte futura, asesinado.

Da la sensación de que el fantasma de Pedro I -que sigue apareciendo a lo largo de toda la historia de la ciudad- es más activo en épocas de desgracias, acontecimientos históricos, etc. Existen numerosos testimonios que afirman haber visto a Pedro I durante la Guerra de 1812 contra Napoleón. Decía el zar en sus apariciones que mientras él estuviera en su ciudad, San Petersburgo no correría peligro y sería invencible. Llama la atención que en este caso, como en muchos cuentos folclóricos relacionados con la figura del zar, se pierde la frontera entre el emperador y su imagen, el Caballero de Bronce. Las creencias de que el zar se levanta de su tumba en la Fortaleza de Pedro y Pablo y recorre por las noches la ciudad, desapareciendo con las primeras campanadas del reloj de la Fortaleza, circularon incluso a principios del siglo XX. La enorme figura se veía en muchos sitios de la ciudad y así el zar-se decía- cuidaba de su creación. De las leyendas urbanas modernas mencionaremos la que narra que el Caballero de Bronce, antes de las inundaciones, desciende de la roca-pedestal y recorre cabalgando las calles de San Petersburgo.

Pero Pedro el Grande no es el único fantasma de San Petersburgo. La mayoría de los edificios históricos de la ciudad báltica alberga a su propio inquilino del más allá. Posiblemente la leyenda más conocida y arraigada se refiere al fantasma del emperador Pablo I (1754-1801), que suele pasearse por el castillo donde fue asesinado en el año 1801. El misterioso y fantasmagórico edificio del palacio Mijáilovski, que parece más una fortaleza que un palacio, no salvó la vida del zar. Después de su muerte el palacio fue entregado a la Escuela de Ingenieros, y los jóvenes estudiantes a menudo veían por los pasillos la figura de un hombre bajito y delgado, ataviado con el uniforme de su época y tocado de tricornio. Antes que los alumnos, los obreros que reformaban el palacio dejaron testimonio sobre este muerto no-muerto. Según ellos, el hombre aparecía de la nada, como si hubiera salido de las paredes, se paseaba majestuosamente por los pasillos y cuando veía a algún trabajador, lo amenazaba con el puño. 
Tristes fantasmas habitan el Palacio Chino, en el complejo palaciego de Oranienbaum. A principios del siglo XX dicho palacio pertenecía al duque G. G. Mecklenburg-Strelitz, que vivía allí con su esposa y su hija Natasha. En 1909 falleció el duque; tres años más tarde falleció su hija. Ambos fueron enterrados en el parque, anexo al palacio. Después de la revolución, las tumbas fueron abiertas y profanadas. Todavía hoy -dicen muchos- se pueden oír en el parque los pasos del duque y los rápidos y ligeros pasitos de la niña.

Cualquiera podía transformarse en un fantasma: se cuenta que el fantasma del reconocido escultor M. I. Kozlovski, durante muchos años profesor de la Academia de Bellas Artes, no puede desvincularse de su lugar de trabajo y aún hoy los estudiantes afirman haber visto la figura del docente durante las inundaciones más fuertes o haber oído cómo, llamando a la puerta, pide entrar susurrando "estoy llamando yo, el escultor Kozlovski del cementerio de Smolensk; en la tumba estoy muy mojado y helado. Abrid".

No solamente los ricos, poderosos, importantes o conocidos se convertían en fantasmas. Asimismo, a finales del siglo XVIII y principios del siglo XIX, se hablaba mucho de un edificio que pertenecía al carpintero-carretero Johann-Albert Ioajím. La casa fue de apartamentos de alquiler y allí, en numerosos habitáculos, vivía gente de los más variopintos oficios: sastres y vendedores, zapateros y modistas, matronas y reparadores de vajilla rota, etc., y de diferente procedencia. La aparición de los cuentos sobre fantasmas en esta colmena se explica en cierto modo por el hecho de que a principios del siglo XIX, cuando nacieron estas leyendas, muchos de los residentes del barrio eran alemanes y, probablemente, trajeron de su país los tradicionales cuentos populares sobre fantasmas. El triste, oscuro y con cierto toque macabro edificio de Ioajím encajaba a la perfección en la visión de un lugar infestado por fantasmas (СИНДАЛОВСКИЙ 1995: 65).

Las creencias populares propiamente rusas siempre atribuían mayores facilidades para convertirse en muertos vivos a los fallecidos por muerte accidental o asesinados. Por eso no es de extrañar que entre estos seres de ultratumba se encuentre el emperador Pedro III, marido de Catalina II, asesinado en un palacio en Ropsha, a las afueras de la capital, en el trascurso de un complot que llevó al trono a su mujer, Catalina, en 1762. Narran que, durante la boda de su hijo Pablo, incluso se sentó a festejar con los demás tan importante acontecimiento.

Pedro III falleció antes de ser coronado oficialmente y, por lo tanto, no podía ser enterrado en el Panteón Imperial de la Catedral de la Fortaleza de Pedro y Pablo. Su hijo Pablo organizó en 1796, al morir la emperatriz Catalina II, su madre, una macabra ceremonia, llevando los restos de su padre a la Catedral, donde puso la corona, según testimonios, sobre el cráneo de su padre, Después enterró a Pedro III en la Catedral, junto a los otros miembros de la familia real. Toda la ceremonia fue impresionante y, para más escarnio, el zar obligó a todos los que de una u otra manera estaban relacionados con el asesinato de su progenitor, a estar presentes en primera fila. Pero aun con estos honores, el difunto Pedro III no encontró la tranquilidad y su fantasma se ve a menudo por los aposentos del Palacio de Oranienbaum.

Curioso es el hecho de que, al parecer, todos los muertos no-muertos de la ciudad, durante sus apariciones, guardan cierta semejanza de comportamiento con el 
que se conocía en sus vidas terrenales. Por ejemplo, según las leyendas urbanas, el fantasma del famoso Rasputin acecha a todos los que pasan por la escalera del edificio donde residía, sometiéndolos a ciertos tocamientos muy atrevidos.

Entre unos y otros, según los archivos de la Policía de San Petersburgo, a principios del siglo XX se consideraba que más de veinte edificios gozaban de mala fama, donde se aseguraba ver a los fantasmas, y donde sucedían cosas macabras e inquietantes. Así, una mansión de la que salían gemidos y música fúnebre por la noche, era denominada El Club de los suicidas. Otro edificio, situado en el centro de la ciudad, se consideraba un lugar de encuentro de muertos camuflados, donde ellos se reunían para jugar a las cartas.

Como ya se ha mencionado anteriormente, los espectros no constituían elementos típicos del folclore tradicional ruso, y las numerosas leyendas que sobre ellos hay en la mitología urbana de San Petersburgo pueden considerarse como influencia de parte de las creencias traídas de sus países por numerosos residentes en la ciudad de origen occidental. Los que sí eran totalmente autóctonos, arraigados en la cultura popular rusa, eran los upiros, muertos vivientes, que poblaban la ciudad con toda naturalidad y en abundancia.

La gran cantidad de leyendas, mitos, anécdotas y cuentos maravillosos relacionados con la ciudad de San Petersburgo la explican los etnógrafos por el hecho de que los campesinos, que constituían la mayor parte de los obreros en el proceso de construcción de la urbe, venían de sus aldeas cargados de tradiciones, costumbres y folclore, con su arraigado sistema de valores y principios. En el nuevo terreno se encontraban con unos fenómenos raros e insólitos para ellos, con otro sistema ético y estético, lo que dio lugar a una curiosa mezcla y a una peculiar mitología urbana basada en la visión del mundo tradicional y que se alimentaba de la poética tradicional, pero que lo transformaba todo y creaba su propio mundo y sistema de imágenes, motivos, fórmulas, clichés, etc. De aquí que la demonología relacionada con la ciudad de Pedro I tiene sus facetas propias y específicas, comparada con las creencias tradicionales rusas, al mismo tiempo que está estrechamente vinculada al folclore popular ruso en general.

La propia historia de San Petersburgo siempre ha tenido dos versiones: una oficial y otra folclórica. La segunda se basaba casi exclusivamente en rumores, leyendas, cuentos, anécdotas, profecías, etc. En el siglo XVIII la cultura escrita, oficial, alababa la nueva capital, la llamaba la octava maravilla del mundo, el Nuevo Paraíso, la Venecia del Norte, la Nueva Roma. Los mejores poetas de su tiempo le dedicaban sus poesías, los más famosos pintores rusos y extranjeros plasmaban en sus obras las imágenes poéticas, bellas y elegantes, de la metrópoli. Sin embargo, paralelamente existía un fuerte rechazo, la directa vinculación de la nueva capital con todo lo antirruso y, más aún, con las fuerzas del mal. Esta visión estaba muy difundida entre campesinos, obreros, soldados, entre los antiguos creyentes, pero asimismo la compartían muchos representantes de las clases altas, aunque, obviamente, a escondidas y temiendo las horribles represalias del zar. El poeta polaco Adam Mickiewicz en su obra Dziady (1823) directamente afirma que San Petersburgo fue construida por Satanás: 
U architektów síawne jest przyslowie,

Ze ludzi rekg byl Rzym budowany,

A Wenecyjg stawili bogowie;

Ale kto widzial Petersburg, ten powie,

Ze budowaly go chyba szatany (MICKIEWICZ 1995: 295).

A lo largo de los tres siglos de su existencia, en la literatura rusa y en las creencias populares es frecuente la percepción de la ciudad como maldita, de aquí todas las desgracias y cataclismos que la afectaban a ella y más aún a todo el país. En su trilogía Хождение по мукам (El camino de los tormentos, 1922-1941), Alekséi Tolstói da su explicación a los importantes y cruciales acontecimientos de principios del siglo XX en Rusia:

Еще во времена Петра Первого дьячок из Троицкой церкви, что и сейчас стоит близ Троицкого моста, спускаясь с колокольни, впотьмах, увидел кикимору - худую бабу и простоволосую, - сильно испугался и затем кричал в кабаке: "Петербургу, мол, быть пусту", - за что был схвачен, пытан в Тайной канцелярии и бит кнутом нещадно.

Так с тех пор, должно быть, и повелось думать, что с Петербургом нечисто. То видели очевидцы, как по улице Васильевского острова ехал на извозчике черт. То в полночь, в бурю и высокую воду, сорвался с гранитной скалы и скакал по камням медный император. То к проезжему в карете тайному советнику липнул к стеклу и приставал мертвец - мертвый чиновник. Много таких россказней ходило по городу.

И совсем еще недавно поэт Алексей Алексеевич Бессонов, проезжая ночью на лихаче, по дороге на острова, горбатый мостик, увидал сквозь разорванные облака в бездне неба звезду и, глядя на нее сквозь слезы, подумал, что лихач, и нити фонарей, и весь за спиной его спящий Петербург - лишь мечта, бред, возникший в его голове, отуманенной вином, любовью и скукой.

Как сон, прошли два столетия: Петербург, стоящий на краю земли, в болотах и пусторослях, грезил безграничной славой и властью; бредовыми видениями мелькали дворцовые перевороты, убийства императоров, триумфы и кровавые казни; слабые женщины принимали полубожественную власть; из горячих и смятых постелей решались судьбы народов; приходили ражие парни, с могучим сложением и черными от земли руками, и смело поднимались к трону, чтобы разделить власть, ложе и византийскую роскошь.

С ужасом оглядывались соседи на эти бешеные взрывы фантазии. С унынием и страхом внимали русские люди бреду столицы. Страна питала и никогда не могла досыта напитать кровью своею петербургские призраки (ТОЛСТОЙ 1961: 5-6).

La aparición de leyendas sobre los muertos vivos se debe en gran parte a la propia historia de San Petersburgo. Se sabe que los primeros trabajadores en la construcción de la ciudad fueron los soldados del ejército regular, los prisioneros suecos y algunos, aunque pocos, campesinos fineses. Pero el grandioso proyecto necesitaba de una masa de trabajadores sin precedentes. En otoño de 1703 trabajaban allí más de veinte mil personas, y en marzo de 1704 fue emitido un ucase que obligaba a enviar desde ochenta y cinco pueblos y ciudades de todas las regiones de Rusia a más de cuarenta mil trabajadores. Al año aparece otro edicto que dictaba enviar de 
cada nueve casas a una persona para trabajos en San Petersburgo y proveer a estos obreros con los alimentos y las herramientas. De hecho, durante muchos años todo el país sostuvo esta pesada carga para construir la espléndida y lujosa ciudad europea. Los obreros vivían en chamizos o chabolas de tierra. Morían de hambre y frío, enfermedades y trabajos inhumanos; los que sobrevivían, al cabo de cierto tiempo regresaban a su lugar de origen y eran reemplazados por nuevos modernos esclavos:

... emitiese edicto tras edicto llamando de todos los lugares del Imperio carpinteros, albañiles, labradores y más labradores; tártaros, chuvashes, cosacos, tantos de Siberia, tantos de Kazán, tantos de cada provincia. No se pagaban salarios; la deserción era crónica; las enfermedades causaban estragos; la muerte hacía su agosto, en aquel delta pantanoso, cubierto de pinos y abedules desmedrados, con el Nevá en crecida constante, o con el intenso frío del invierno ártico, allí donde el Zar Reformador quería que brotase su paraíso (COWLES 1975: 63).

Se calcula que durante el reinado de Pedro I Rusia perdió la cuarta parte de su población a causa de las guerras, los castigos y las ejecuciones de los rebeldes, la movilización forzosa de campesinos para la construcción de la nueva capital, etc. Algunos historiadores hablan de más de doscientas mil personas que fallecieron en las dos décadas de la construcción de la ciudad. Según uno de los estudiosos más reconocidos de la historia de Rusia, V. O. Kliuchevski: “едва ли найдется в военной истории побоище, которое вывело бы из строя больше бойцов, чем сколько легло рабочих в Петербурге и Кронштадте. Петр называл новую столицу своим «парадизом»; но она стала великим кладбищем для народа" ("apenas encontramos en la historia bélica una batalla que pusiera fuera de combate a más combatientes que los obreros que fallecieron en Petersburgo y Kronstadt durante su fundación. Pedro llamaba a su capital "un paraíso", pero ella se convirtió en gran cementerio para el pueblo" (КЛЮЧЕВСКИЙ 2002: 28).

Las palabras del historiador tienen un doble significado, tanto metafórico como directo; se sabe que durante los primeros años de su existencia en San Petersburgo no había cementerios. Según testimonios de viajeros extranjeros que visitaron la ciudad durante su construcción, los cadáveres de los fallecidos se enterraban en el mismo lugar donde les encontraba la muerte. Un súbdito del Duque de HolsteinGottorp, de nombre F. V. Berjgoltz, escribe en su diario que "a los campesinos que morían en el trabajo en la fortaleza de Petersburgo los enterraban enseguida en el mismo sitio". Así, la ciudad representaba una enorme fosa común, lo que es muy importante para comprender las bases del tan arraigado y persistente mito de los muertos vivientes en San Petersburgo, confirmando un conocido dicho: que San Petersburgo está fundada sobre huesos humanos. Si regresamos a las creencias eslavas referentes a los upiros, recordaremos que una de las clases de fallecidos que tenían más posibilidades de convertirse en upiros eran los заложные покойники, "muertos tapados, cubiertos", quienes por alguna razón (la vida pecaminosa, por ser brujo, suicida, borracho, etc.) podrían no ser aceptados por la tierra, y así los dejaban sin enterrar, simplemente tapándolos, cubriéndolos con ramas, troncos, etc. Automáticamente entraban en el grupo de los "muertos tapados" los fallecidos por 
epidemias, que no eran enterrados según el ritual ortodoxo, o los caídos en las batallas y a los que no les daban cristiana sepultura.

Las numerosas inundaciones que se cobraron miles de vidas humanas reforzaban la percepción de la ciudad como un foco de posibles upiros, puesto que justamente los ahogados, según las creencias populares, formaban gran parte de los заложные покойники, quienes a su vez se convertían en upiros.

Las creencias en los muertos vivientes y los muertos tapados no impidieron a las autoridades, ya en el siglo XX, tomar decisiones que iban contra la cultura cristiana y popular. Así, la aparición en el mismísimo centro de la ciudad de un cementerio de las víctimas de la Revolución Rusa de 1917 fue considerado por la población creyente como un atentado contra la tradición ortodoxa, que obligaba a enterrar a los difuntos dentro de un cementerio o cerca de una iglesia, lo que sumado a los cataclismos de la Revolución y la Guerra Civil reavivó de manera espectacular el mito de la ciudad del Anticristo y su visión apocalíptica.

La convicción de la existencia de lugares peligrosos por la posibilidad de aparición de numerosos upiros se mantuvo incluso hasta mediados del siglo XX. De aquí, se consideraban focos de upiros las fosas comunes donde fueron enterradas las víctimas de los novecientos días del asedio de Leningrado durante la II Guerra Mundial. Personalmente hemos recogido una leyenda urbana sobre un edificio cerca del Arco de Triunfo de Narva (Нарвские ворота). Construido todo el barrio a principios del siglo XX, fue bombardeado por la aviación nazi, salvándose algunas de las casas por realizar sus vecinos y habitantes - tanto creyentes como ateos- unas procesiones con iconos y confalones alrededor de las mismas. Uno de los edificios que no fue protegido por los rezos y cánticos fue destruido, quedando allí un inmenso hoyo o cráter, a la vez una enorme fosa común. Teniendo en cuenta que es así como se engendraban los upiros, no resultó nada extraño que el bloque de pisos posteriormente edificado sobre esta fosa, sin preocuparse las autoridades de enterrar a las víctimas, fuera considerado maldito y tuviera muy mala fama entre los vecinos.

Por otro lado, hay que tener en cuenta que, en el trascurso del desarrollo urbanístico, los emplazamientos de los cementerios de la ciudad constantemente se cambiaban. Tomando en consideración la ley de la Emperatriz Isabel -que tenía pánico a todo lo relacionado con la muerte-, la cual obligó a ubicar los camposantos siempre en las afueras de la capital (a unos 200 metros como mínimo de la frontera urbana), parece obvio que, ampliando los límites de la ciudad, se alejaban los lugares de enterramiento y en su lugar se construían edificios, se organizaban parques y plazas. Tan sólo a principios del siglo XX fueron destruidos catorce cementerios y desgraciadamente nadie se preocupó de trasladar los restos descubiertos a otros lugares para darles una digna sepultura. Personalmente he sido testigo de unas obras que estaban realizándose a finales de los años 80 en el barrio cercano al Arco de Triunfo de Moscú (Московские ворота) justamente sobre los enterramientos sin siquiera retirar previamente las cruces y las lápidas funerarias.

Por esta razón no es de extrañar que en la visión popular San Petersburgo se considerase como una ciudad con una gran proliferación de muertos vivientes. Por otro lado, el tema de los muertos vivos siempre ha sido muy recurrente en la literatura rusa. En las obras de muchos escritores, tales como Aleksandr Pushkin, Nikolái 
Gógol, Fiódor Dostoievski, Alekséi Tolstói y Andréi Bely, entre otros, se aprecia el motivo de los живые мертвецы que rodean a los personajes. En algunos casos la aparición de estos muertos en San Petersburgo no está condicionada directamente por la propia ciudad, los upiros no son producto de la urbe, sino que actúan allí porque los personajes pertenecen a algún estrato social que explica su presencia en la capital. Pero tampoco podemos afirmar que estos muertos vivientes surgen en la ciudad por casualidad. El inquietante paisaje urbano influye en la creación de una especial, mística y enigmática atmósfera. El clima de San Petersburgo con su cielo gris, la frecuente niebla, la lluvia, las fantásticas noches blancas, su paisaje con canales y ríos, con los edificios reflejados en el agua negra, los ligeros puentes sobre los canales, el granito de sus malecones, la propia arquitectura, bella, pero al mismo tiempo muy distante y fría, ayudaba a crear estos mitos.

Город весной, летом и осенью существует как бы в двух измерениях, причудливо отражаясь в глади или ряби Невы, бесчисленных речек, каналов, прудов, фонтанов и столь характерных для Петербурга лужах, отчего получает фантастическое (изломанное, сдвинутое) «обратное» продолжение; это подобие, в отличие от реальных неподвижных домов, решёток, памятников, кажется живым, наделённым настроением, изменчивым и капризным. Человек, находящийся на пересечении реального пространства и его отражённого «двойника», поневоле видит и чувствует себя раздвоенным. Если добавить сюда присущую петербургской архитектуре страсть к большим цельным окнам, в которых отражается та же Нева и напоминающее её петербургское небо; моду на ложные окна и разных размеров зеркала в интерьерах парадных залов, гостиных, приёмных, театральных фойе и т. п., когда каждый видит себя одновременно в нескольких ракурсах, - то начинаешь понимать особую - зеркальную - доминанту петербургской культуры, петербургского стиля, петербургский дискомфорт ... (НЕКРЫЛОВА 1998: 646).

El reflejo aquí no es una simple repetición de la imagen real, es una frontera entre dos mundos, es el espejo mágico de los brujos y adivinos, de los vampiros y fantasmas: "Дом, опрокинутый в воду, отражался в зеркальных зыбях её с своим освещением, со всеми своими формами и даже с самим цветом стен своих" (ОЛГИН 1999: 379) у es allí, en este edificio inverso, que no se sabe si es real o soñado, donde se celebran los festines diabólicos. No sería por lo tanto nada extraño que la atmósfera enigmática, fantasmagórica, misteriosa e ilusoria de la Venecia del Norte empapase la gran mayoría de las obras rusas pertenecientes al género de la novela gótica y la literatura rusa en general:

Когда читаешь подряд рассказы, повести, романы XIX-начала XX в., создаётся впечатление, что далёкие по времени и убеждениям писателя были уверены в существовании двойного населения северной столицы, что в отличие от других городов и весей умершие здесь не покидают своих домов, улиц, департаментов, продолжают пребывать рядом. Невидимые днём и в солнечную погоду, они появляются ночью, выходят из щелей домов, из завесы дождя или мокрого снега; подобно шекспировским ведьмам, материзуются туманом, испарениями каналов и сточных канав, сырыми и тёмными подъездами дешёвых доходных зданий (НЕКРЫЛОВА 1998: 646). 
La línea roja entre la vida de los muertos y la de los vivos es tan frágil que aquéllos intervienen con toda tranquilidad en la existencia de éstos, conviven con ellos como si fuera tal cosa en una ciudad donde nada es lo que parece y donde todos sus habitantes, de una manera u otra, están preparados y mentalizados para encontrarse con las fuerzas del más allá. La sensación de estar viviendo en una ciudad de los muertos vivos es característica para muchos personajes de la literatura rusa y a la vez refleja la visión de sus autores:

Город, утвержденный на костях своих строителей, не мог не восприниматься как колоссальный Некрополь и как гигантское надгробье. Начиная с Гоголя и Достоевского, Петербург подается в поэтике иношнего мира, обители теней, призраков и фантомов. Белые ночи и газовое освещение улиц довершили фантасмагорический облик призрачного города, населенного живыми мертвецами (ИСУПОВ 1993: 68).

Еn "Миазм" ("Miasma", 1868), obra del poeta del siglo XIX Yákov Polonski, nos encontramos en el majestuoso palacio de Stróganov, donde una desolada madre llora la muerte de su hijo. De repente, como si saliera de la nada, ante sus ojos aparece la diminuta figura de un campesino, delgado y pobremente vestido. “¿De dónde has salido?”, le pregunta la mujer. "A través de una grieta", le contesta el hombrecillo. Y a continuación le explica que el palacio está sobre los enterramientos de los obreros fallecidos durante la construcción de la ciudad. El muerto cuenta todas las penurias que le llevaron a la muerte y pide perdón a la madre porque al niño lo ahogó el suspiro, pesado como una piedra, del campesino enterrado bajo el palacio. Al no poder estar más en un lugar así, la angustiada mujer huye del palacio, lo pone en venta y el lujoso edificio es abandonado 7 .

\footnotetext{
7 Дом стоит близ Мойки - вензеля в коронках/Скрасили балкон./В доме роскошь - мрамор - хоры на колонках -/Расписной плафон.// Шумно было в доме: гости приезжали -/Вечера - балы;/Вдруг все стало тихо - даже перестали/ Натирать полы.// Няня в кухне плачет, повар снял передник,/ Перевязь - швейцар:/ Заболел внезапно маленький наследник -/ Судороги, жар.../Вот перед киотом огонек лампадки.../ И хозяйка-мать/ Приложила ухо к пологу кроватки -/ Стонов не слыхать.// «Боже мой! ужели?.. Кажется, что дышит...»/ Но на этот раз/ Мнимое дыханье только сердце слышит -/ Сын ее погас.// «Боже милосердый! Я ли не молилась/ За родную кровь!// Я ли не любила! Чем же отплатилась/ Мне моя любовь!/ Боже! страшный боже! Где ж твои щедроты,/ Коли отнял ты/ У отца - надежду, у моей заботы - /Лучшие мечты!»// И от взрыва горя в ней иссякли слезы, -/ Жалобы напев /Перешел в упреки, в дикие угрозы,/ В богохульный гнев./ Вдруг остановилась, дрогнула от страха,/ Крестится, глядит:/ Видит - промелькнула белая рубаха,/ Что-то шелестит./ И мужик косматый, точно из берлоги/Вылез на простор,/ Сел на табурете и босые ноги/ Свесил на ковер.// И вздохнул, и молвил: «Ты уж за ребенка /Лучше помолись;/ Это я, голубка, глупый мужичонко, - /На меня гневись...»// В ужасе хозяйка -жмурится, читает/ «Да воскреснет бог!»/ «Няня, няня! Люди! - Кто ты? - вопрошает. - Как войти ты мог?»// «А сквозь щель, голубка! Ведь твое жилище/ На моих костях,/ Новый дом твой давит старое кладбище -/ Наш отпетый прах.// Вызваны мы были при Петре Великом... /Как пришел указ - /Взвыли наши бабы, и ребята криком/Проводили нас - //И, крестясь, мы вышли. С родиной проститься/ Жалко было тож //Подрастали детки, да и колоситься/Начинала рожь...// За спиной-то пилы, топоры несли мы:/ Шел не я один, -/К Петрову, голубка, под Москву пришли мы,/А сюда в Ильин.//Истоптал я лапти, началась работа, /Печали спешить: /Лес валить дремучий, засыпать болота,/Сваи колотить, - //Годик был тяжелый. За Невою, в лето/ Вырос городок! //Прихватила осень, - я шубейку где-то/ Заложил в шинок. //К зиме-то пригнали новых на подмогу; /А я слег в шалаш; /К утру, под рогожей, отморозил ногу, Умер и - шабаш! //Вот на этом самом месте и зарыли, -/ Барыня, поверь, /В те поры тут ночью только волки выли -/ То ли, что теперь! //Ге! теперь не то что... - миллион народу... /Стены выше гор... /Из подвальной Ямы выкачали воду - /Дали мне простор... //Ты меня не бойся, - что я? - мужичонко! /Грязен, беден, сгнил,/Только вздох мой тяжкий твоего ребенка /Словно придушил...»// Он исчез - хозяйку около кроватки/ На полу нашли; /Появленье духа к нервной лихорадке,/ К бреду отнесли. //Но с тех пор хозяйка в северной столице/ Что-то не живет;/ Вечно то в деревне, то на юге, в Ницце.../ Дом свой продает, - //И пустой стоит он, только дождь стучится/ В запертой подъезд,/Да в окошках темных по ночам слезится /Отраженье звезд (ПОЛОНСКИЙ 1868).
} 
El campesino del poema de Polonski, obviamente, es una imagen poética y anónima por definición, aunque detrás de este personaje podrían estar miles y miles de ciudadanos rusos que encontraron la muerte en los pantanos de la región báltica.

Este recurrente motivo de la ciudad cementerio penetra todas las obras de Dostoievski. Recordaremos la comparación con un ataúd del estrecho, oscuro habitáculo donde residía Raskólnikov en su novela Преступление и наказание (Сrimen $y$ castigo).

Los antiguos camposantos desaparecían de la faz de la tierra, crecían nuevos barrios y se construían nuevos y modernos edificios, pero no desaparecía la maldición y se cumplía la macabra profecía: los muertos se vengaban de los vivos, llevándolos a su mundo antes de hora o convirtiéndoles a su vez en otros upiros. Así, de día, la ciudad estaba llena de muertos vivientes y por la noche resucitaban de sus tumbas numerosos cadáveres. Tanto unos como otros llevaban una vida mucho más activa y dinámica que la de sus dobles vivos, los propios petersburgueses con su triste, aburrida, gris e insignificante existencia. La paradoja consiste en que, justamente al morir y convertirse en fantasmas o en muertos vivientes, los habitantes de la fría ciudad empezaban a existir de verdad. En la famosa novela "Шинель" ("El Capote", 1842) de Nikolái Gógol, tan sólo al fallecer el pobre oficinista Bashmachkin empieza a tener independencia, se convierte en una figura activa y hasta él mismo atraca a los demás para robarles un capote, que tanto significaba para él.

Comparados con otras criaturas de ultratumba y con los tradicionales upiros rusos, los muertos vivientes de San Petersburgo no temen la luz del día, se desenvuelven con toda la tranquilidad y naturalidad entre los vivos, se inmiscuyen en sus asuntos y es muy difícil distinguirlos. Así, en la novela Любовь и смерть (El aтоr y la muerte, 1834) del escritor del siglo XIX O. I. Senkovski, se presenta ante el lector una romántica historia de amor imposible entre dos jóvenes: la mujer está casada y los enamorados no tienen futuro. En la narración observamos una serie de motivos recurrentes en la novela romántica y gótica: el intercambio de anillos, que se comprende como una forma de casarse en la otra vida, la temprana muerte de la joven, etc. El joven, desolado, acude diariamente al cementerio de Smolensk, uno de los más antiguos camposantos de San Petersburgo, pero no se atreve a entrar en esta necrópolis. Una vez superado el miedo y a plena luz del día, encuentra allí a su amada paseando tranquilamente. Después de largos paseos y cariñosas conversaciones, la mujer lleva al joven hasta su tumba, entran allí y en una acogedora habitación lo invita a quedarse para siempre con ella (СЕНКОВСКИЙ 2006: 316-361).

San Petersburgo crea sus propios muertos vivientes, como el desdichado Bashmachkin, que no hubiera podido aparecer en ningún otro lugar sino en la capital burocrática del Imperio; o alberga los monstruos que no son producto directo de la ciudad, pero que se encuentran muy a gusto en sus paisajes urbanos, en casas humildes de los barrios periféricos o en las húmedas colmenas al lado de los canales con sus olores a pantano, en la oscuridad de los patios sin luz y aire, como asimismo en los salones de fiesta de la nobleza rusa, en aislados palacetes y casas. Hasta en el palacio del zar había un upiro. En el poema del poeta Nikolái Zabolotski "Oфорт" ("Aguafuerte", 1927), leemos: "Se oyó un grito estremecedor en la sala: ¡El muerto se ha escapado de la casa del zar!” En la descripción del cadáver, que 
pasea por la ciudad, es llamativo el detalle de que el muerto viviente "está lleno hasta la garganta de las aguas subterráneas", que otra vez más nos devuelve a la naturaleza pantanosa de la ciudad ${ }^{8}$.

En la mitología de San Petersburgo es muy frecuente el motivo de la conversión de un humano en un ser diabólico, y comparando con las creencias populares rusas en general, para ello no era necesario ningún conjuro, ninguna condición especial: bastaba morir o simplemente encontrarse en una oscura y desierta calle, penetrar en la fría y húmeda niebla, desaparecer en la blancura de la noche. Una de las obras más famosos de la literatura rusa que trata el tema de los muertos vivientes en San Petersburgo es el poema del simbolista Aleksandr Bloch "Пляски смерти" ("Las danzas de la muerte", 1912-1914), donde los protagonistas son la propia Muerte y los muertos que viven y forman parte de la sociedad de la capital imperial.

El motivo de los muertos vivientes sigue activo en la narrativa del siglo XX. Daniil Jarms escribe el cuento "Старуха" ("La anciana"), donde con su inconfundible estilo, mezclando humor negro y rasgos fantasmagóricos, describe la absurda vida del Leningrado de los años 30. El literato cuenta una leyenda urbana sobre los muertos vivientes que son casi naturales en la ciudad:

- Покойники, - объясняли мне мои собственные мысли, - народ неважный. Их зря называют покойники, они скорее беспокойники. За ними надо следить и следить. Спросите любого сторожа из мертвецкой. Вы думаете, он для чего поставлен там? Только для одного: следить, чтобы покойники не расползались. Бывают, в этом смысле, забавные случаи. Один покойник, пока сторож, по приказанию начальства, мылся в бане, выполз из мертвецкой, заполз в дезинфекционную камеру и съел там кучу белья. Дезинфекторы здорово отлупцевали этого покойника, но за испорченное белье им пришлось рассчитываться из своих собственных карманов. А другой покойник заполз в палату рожениц и так перепугал их, что одна роженица тут же произвела преждевременный выкидыш, а покойник набросился на выкинутый плод и начал его, чавкая, пожирать. А когда одна храбрая сиделка ударила покойника по спине табуреткой, то он укусил эту сиделку за ногу, и она вскоре умерла от заражения трупным ядом. Да, покойники народ неважный, и с ними надо быть начеку (XАPMC 1991: 116).

Aparte de su carácter rocambolesco, en este episodio se observa un fenómeno anotado por los antropólogos: "Новоумершие вообще плохо настроены и готовы причинить зло тем, кто их пережил... Как бы добр ни был покойник при жизни, стоит ему испустить дух, чтобы душа его стала помышлять лишь о том, чтобы причинять зло" ("Los recién muertos en general son malintencionados y están dispuestos a causar daño a todos los que los sobrevivieron... Por muy buena persona que fuese el muerto en vida, en cuanto fallece, su alma solamente piensa cómo causar daño" КРАСИЛЬНИКОВ 2007: 595). Por eso es comprensible el

\footnotetext{
8 И грянул на весь оглушительный зал:/»Покойник из царского дома бежал!»//Покойник по улицам гордо идет,/Его постояльцы ведут под уздцы,Он голосом трубным молитву поетИ руки вздымает наверх.//Он в медных очках, перепончатых рамах,/Переполнен до горла подземной водой./Над ним деревянные птицы со стуком/Смыкают на створках крыла./А кругом громобой, цилиндров бряцанье/И курчавое небо, а тут Городская коробка с расстегнутой дверью/И за стеклышком - розмарин (ЗАБОЛОЦКИЙ 1998).
} 
miedo que pasó un miliciano en una historia verídica contada por el escritor Mijaíl Veller en su libro Легенды Невского Проспекта (Leyendas de la Avenida Nevski). De su experiencia profesional de médico de urgencias recuerda una anécdota que sucedió a un miliciano, cuya unidad era responsable de hacer la guardia nocturna en el cementerio Piskarevski, un memorial a las víctimas del asedio de Leningrado. Las obligaciones se consideraban fáciles, ya que "los muertos, igual que sus monumentos, eran por lo general gente tranquila y no estaba inclinada hacia los escándalos. No molestaban por tonterías, y no ofrecían sobornos. Por eso los milicianos se aburrían" (ВЕЛЛЕР 2002: 291). Además, el trabajo no solamente era tranquilo, sino hasta económicamente ventajoso: por la noche los guardias se metían en la fuente a la que los turistas tenían costumbre de echar algunas moneditas. Después de zambullirse en el agua fría, el miliciano a quien le tocaba tal aventura se calentaba mediante un buen trago de vodka. El negocio iba viento en popa hasta que se dio un tragicómico suceso. Tras tomar su dosis de vodka, el miliciano necesitaba salir urgentemente a hacer sus necesidades y, sin pensarlo dos veces, se internó en la oscuridad de la noche para aliviar sus fluidos sobre una tumba. Cuál no sería su horror al sentir que alguien lo tenía agarrado por la espalda, y cuanto más intentaba él levantarse, más lo empujaban hacia el suelo. A lo lejos, el reloj marcaba las doce. El miliciano gritaba, presa de gran terror. "La fuerza del más allá lo tira a la tierra. Has profanado un lugar sagrado, has profanado las cenizas, y con su mano huesuda tira de él hacia sí el muerto" -narra el escritor.

Al cabo de media hora acudieron los otros milicianos a buscar a su compañero y lo encontraron aullando, totalmente fuera de sí, con los bajos de su abrigo de uniforme enganchado a un pico de la verja metálica de una tumba. Por mucho que intentaban tranquilizarlo y animarlo, no pudieron hacer nada. El joven seguía aullando y no hubo más remedio que, de mañana, llamar a la ambulancia, que llevó al desgraciado miliciano a un manicomio (ВЕЛЛЕР 2002: 291-293).

Esta tragicómica historia nos demuestra hasta qué punto hay que estar alerta en la ciudad de los espejismos y espectros, donde se confunde la realidad con la fantasía, donde los muertos y los vivos conviven en el mismo espacio rodeado de palacios, canales y puentes.

\section{Referencias bibliográficas}

COWLES, V. (1975): Los Romanov, Editorial Noguer, Barcelona.

HUGHES, L. (1998): Russia in the Age of Peter the Great, New Haven, CT; Yale University Press, London.

HUGHES, L. (2002): Peter the Great: A Biography, New Haven, CT; Yale University Press, London.

MASSIE, R. K. (1987): Pedro el Grande: su vida y su mundo, Alianza Editorial, Madrid.

MICKIEWICZ, A. (1995): Dziela, Tom 3, Czytelnik, Warszawa.

SCHAKOVSKOY, Zinaida (1964): Precursors of Peter the Great, London.

АНИСИМОВ, Е. В. (1989): Время петровских реформ, Лениздат, Ленинград.

БУГАНОВ, В. И. (1989): Петр Великий и его время, Наука, Москва.

БУРОВСКИЙ, А. М. (2008): Петр Первый. Проклятый император, Эксмо, Москва. 
ВАЛИШЕВСКИЙ, К. Ф. (2003): Петр Великий, Терра, Москва.

ВЕЛЛЕР, М. (2002): Легенды Невского Проспекта, АСТ, Москва.

Дом Романовых: биографические сведения о членах ияарственного дома, их предках и родственниках (1992): Санкт-Петербург.

ЗАБОЛОЦКИЙ, Н. (1998): Меркнут знаки Зодиака, Эксмо-Пресс, Москва.

ИСУПОВ, К. (1993): "Историческая мистика Петербурга" en Метафизика Петербурга, Эйдос, Санкт-Петербург, сс. 63-73.

КАРАМЗИН, Н. М. (1988): История государства Российского, Кн.1-3, Москва.

КЛЮЧЕВСКИЙ, В. О. (2002): “Лекция LXIV: Промышленность и торговля. План и приёмы деятельности Петра в этой области. Вызов иностранных мастеров и фабрикантов. Посылка русских людей за границу. Законодательная пропаганда. Промышленные кампании, льготы. Ссуды и субсидии. Увлечения, неудачи и успехи. Торговля и пути сообщения" еn КЛЮЧЕВСКИЙ, В. О. Русская история: Полный курс лекиий, т. 3, АСТ, Харвест, Москва.

КОСТОМАРОВ, Н. И. (1992): Русская история в жизнеописаниях её главнейших деятелей, Книга III, Книга и бизнес, Москва.

КРАСИЛЬНИКОВ, Р. Л. (2007): “《Живой труп» в русской литературе” еn Русская культура нового столетия: Проблемы изучения, сохранения и использования историкокультурного наследия, Книжное наследие, Вологда, сс. 594-600.

ЛЯПИНА, Л. Е. (2010): Мир Петербурга в русской поэзии: Очерки исторической поэтики, Нестор-история,Санкт-Петербург.

НЕКРЫЛОВА, А. (1998): “Народная демонология в литературе. Материалы к словарю” еп ВЛАСОВА, Марина. Русские суеверия. Энииклопедический словарь, Азбука, Санкт-Петербург, сс. 609-651.

ОЛГИН, В. Н. (1999): “Странный бал”, еп Русская готическая проза, Том 1, ТерраКнижный клуб, Москва, сс. 375-388.

ПАВЛЕНКО, Н. И. (1994): Петр Великий, Мысль, Москва.

Петр Великий: pro et contra: Личность и деяния Петра I в оценке русских мыслителей и исследователей: Антология (2001): РХГИ, Санкт-Петербург.

ПОЛОНСКИЙ, Я. Миазм, http://www.world-art.ru/lyric/lyric.php?id=15329

ПЫЛЯЕВ, М. И. (1990): Старый Петербург, ИКПА, Москва: репринтное издание: Старый Петербургъ: разсказы изъ былой жизни столицы, Изданіе А. С. Суворина, С.-Петербург, 1889.

СЕНКОВСКИЙ, О. И. (2006): “Любовь и смерть” еn Русская готика: Белое привидение, Азбука-классика, Санкт-Петербург, сс. 316-361.

СИНДАЛОВСКИЙ, Н. (1994): Петербургский фольклор, Максима, Санкт-Петербург.

СИНДАЛОВСКИЙ, Н. А. (1995): Легенды и мифы Санкт-Петербурга, Ленинградская галерея, Санкт-Петербург.

СИНДАЛОВСКИЙ, Н. (2009): Призраки Северной столиџы. Легенды и мифы питерского Зазеркалья, Центрполиграф, Санкт-Петербург.

ТОЛСТОЙ, А. (1961): Хождение по мукам. Книга первая и вторая, Художественная литература, Москва.

ТОПОРОВ, В. М. (2003): Петербургский текст русской литературы, Искусство, Санкт-Петербург.

ТРАХТЕНБЕРГ, Л. А. (2005): “Сумасброднейший, Всешутейший и Всепьянейший собор" еп Одиссей: Человек в истории, Наука, Москва, сс. 89-118.

ФЕДОТОВ, Г. (2006): “Самые известные призраки Санкт-Петербурга”, Аномальные новости, 29 (299).

ХАРМС, Д. (1991): Старуха: Рассказы, сцены, повесть, Юнона, Москва. 
ЧИСТЯКОВ, А. С. (1992): История Петра Великого, Буклет, Москва: Репринтное воспроизведение издания 1903 г.

ЩЕГЛОВ, А. (2010): “Всешутейший” царь-антихрист Петр Первый и его кощунства, http://www.staropomor.ru/posl.vrem\%285\%29/vseshutejshij.html 